\title{
PERTUMBUHAN PRODUKTIVITAS PERUSAHAAN MANUFAKTUR INDONESIA DAN PENANAMAN MODAL ASING: PENERAPAN METODE DEKOMPOSISI
}

\author{
Suyanto \\ Fakultas Bisnis dan Ekonomi Universitas Surabaya \\ Jalan Raya Kalirungkut Surabaya 60293 \\ E-mail: suyanto@ubaya.ac.id
}

Diterima 14 Desember 2011 / Disetujui 18 April 2012

\begin{abstract}
This paper examines the productivity growth of Indonesian local firms in relation to foreign direct investment (FDI). Using the survey data of manufacturing firms in Indonesia from 1988 to 2000, the paper decomposes the productivity growth of Indonesian manufacturing firms into three important sources: technical efficiency change, technological progress, and scale efficiency change. The results show that the average total factor productivity (TFP) growth between 1988 and 2000 is 3.51, and the major source contributed to the growth come from technological progress. The interesting finding appears when the data is grouped into foreign firms and domestic firms. It is found that foreign firms have larger productivity growth compared to domestic firms, especially during the period of crisis onwards.
\end{abstract}

Keywords: productivity, Indonesian manufacturing, technical efficiency, technological progress, scale efficiency

\begin{abstract}
Abstrak: Tulisan ini mengkaji pertumbuhan produktivitas perusahaan lokal Indonesia dikarenakan masuknya penanaman modal asing (PMA). Dengan memanfaatkan data survei perusahaan manufaktur oleh Badan Pusat Statistik (BPS) periode 1988-2000, tulisan ini mendekomposisi pertumbuhan produktivitas (productivity growth) perusahaan manufaktur Indonesia menjadi tiga sumber penting: perubahan efisiensi teknis, kemajuan teknologi, dan perubahan efisiensi skala. Hasil memperlihatkan bahwa rata-rata pertumbuhan produktivitas total (TFP) antara 1988 dan 2000 adalah 3,51, dan sumber utama yang berkontribusi terhadap pertumbuhan produktivitas berasal dari kemajuan teknologi. Temuan menarik muncul ketika data dibagi menjadi dua kelompok: perusahaan asing dan perusahaan lokal. Ditemukan bahwa perusahaan asing mengalami pertumbuhan produktivitas yang lebih besar daripada perusahaan lokal, khususnya pada periode krisis ekonomi.
\end{abstract}

Kata Kunci: produktivitas, manufaktur Indonesia, efisiensi teknis, kemajuan teknologi, efisiensi skala

\section{PENDAHULUAN}

Manfaat produktivitas perusahaan lokal, yang diperoleh dari Penanaman Modal Asing (PMA), seringkali diidentikkan dengan kemajuan teknologi. Perusahaan multinasional (MNC) membuka cabang di negara tujuan dan mentransferkan teknologi baru ke cabang tersebut, dan proses transfer teknologi ini kemudian diimitasi oleh perusahaan lokal. Sehingga, kehadiran MNC diasosiasikan dengan proses demonstrasi dan imitasi, yang meningkatkan produktivitas perusahaan lokal melalui transfer teknologi. Argumen seperti ini konsisten dengan penggunaan fungsi produksi yang sesuai dengan standar praktek umum, yang mengukur nilai mean dari data observasi. Asumsi yang dipergunakan adalah perusahaan beroperasi pada tingkat efisiensi penuh (full efficiency) dan 
tingkat kembalian yang konstan (constant return to scale).

Dalam dunia nyata, kedua asumsi tersebut sangat sulit terpenuhi dan tidak nyata (Mahadevan, 2003; Suyanto et al., 2009). Perusahaan biasanya beroperasi pada tingkat efisiensi yang tidak penuh (below full efficiency) dan tingkat kembalian yang bervariasi (variable return to scale). Sehingga, manfaat produktivitas perusahaan lokal dari keberadaan MNC tidak hanya bersumber dari kemajuan teknologi (technological progress), tetapi juga berasal dari peningkatan efisiensi teknis (technical efficiency change) dan peningkatan skala efisiensi (scale efficiency change). Dengan demikian, manfaat produktivitas perusahaan lokal dari adanya PMA, terbagi atas tiga komponen: kemajuan teknologi, peningkatan efisiensi teknis, dan peningkatan skala efisiensi.

Selama ini, dampak produktivitas yang bersumber dari peningkatan efisiensi teknis dan peningkatan skala efisiensi terabaikan dalam literatur. Apabila dampak produktivitas memang berasal juga dari kedua sumber ini, maka hasil kajian empiris yang hanya didasarkan pada kemajuan teknologi tidak mencakup secara komprehensif sumber peningkatan produktivitas, dan cenderung tidak mewakili kenyataan. Karena itu, kajian komprehensif tentang peningkatan produktivitas perusahaan lokal dari tiga komponen produktivitas merupakan suatu kebutuhan dalam literatur. Dengan bantuan metode dekomposisi produktivitas, dapat diperoleh ketiga komponen tersebut.

Secara umum, konsep produktivitas dari PMA berkembang dari ide dasar bahwa PMA memiliki dampak makro dan mikro bagi perekonomian negara tujuan.Secara makro, PMA berkontribusi pada peningkatan akumulasi modal, lapangan kerja baru, dan pendapatan pajak. Kontribusi makro ini sering dikenal dengan kontribusi langsung, yang dapat langsung terlihat ketika PMA dilakukan. Secara mikro, PMA memberikan kontribusi dalam bentuk eksternalitas pengetahuan (knowledge externalities). Eksternalitas pengetahuan ini merupakan manfaat tidak langsung yang terjadi melalui mekanisme non-pasar (Liu, 2008). Proses eksternalitas ini terjadi ketika pengetahuan yang ditransfer oleh
MNC ke cabangnya di negara tujuan, memiliki karakteristik barang publik yang bisa dicontoh dan diimitasi oleh perusahaan lokal. Eksternalitas ini dikenal sebagai efek rembesan pengetahuan (knowledge spillovers).

Efek rembesan pengetahuan ini, dalam literatur PMA, dapat berbentuk tiga hal penting, yaitu efek rembesan dalam bentuk peningkatan produktivitas (productivity spillovers), efek rembesan dalam bentuk kemampuan akses pasar internasional (market-access spillovers), dan efek rembesan dalam bentuk peningkatan profit (pecuniary spillovers) (lihat misalnya Gorg and Strobl, 2004; Haskel, 2007). Dari ketiga efek rembesan ini, peningkatan produktivitas merupakan efek yang paling sering menjadi fokus kajian dalam literatur pada dua puluh tahun belakangan ini. Pemerintah di berbagai negara bersaing dalam menarik minat PMA untuk mendirikan cabang, dengan argumen keberadaan MNC akan meningkatkan produktivitas perusahaan lokal. Proses peningkatan produktivitas terjadi ketika MNC mentransfer pengetahuan ke perusahaan cabang, dan dalam proses transfer pengetahuan ini perusahaan lokal akan mampu menginternalisasi pengetahuan ini melalui efek rembesan (spillovers).

Berdasarkan argumen ini, dapat dijelaskan bahwa transfer pengetahuan oleh MNC ke perusahaan cabang mencakup dua proses yang berbeda. Pertama, proses transfer pengetahuan dari MNC ke perusahaan cabangnya (knowledge transfer). Kedua, proses transfer pengetahuan dari MNC ke perusahaan domestik (knowledge spillovers). Gambar 1 memperlihatkan kedua proses transfer pengetahuan ini.

Gambar 1 memperlihatkan bahwa ketika MNC men-transfer-kan pengetahuannya ke perusahaan cabang di negara tujuan, pengetahuan tersebut memiliki sifat barang publik. Dalam artian bahwa, pengetahuan yang ditransfer dapat ditiru dan diadopsi oleh perusahaan lokal. Proses transfer pengetahuan ini memiliki efek rembesan pengetahuan melalui empat saluran: (1) kompetisi, (2) efek demonstrasi, (3) mobilitas pekerja, dan (4) hubungan vertikal industri. Kompetisi dari perusahaan asing mendorong perusahaan lokal untuk mempertahankan pangsa pasarnya melalui peningkatan produk- 


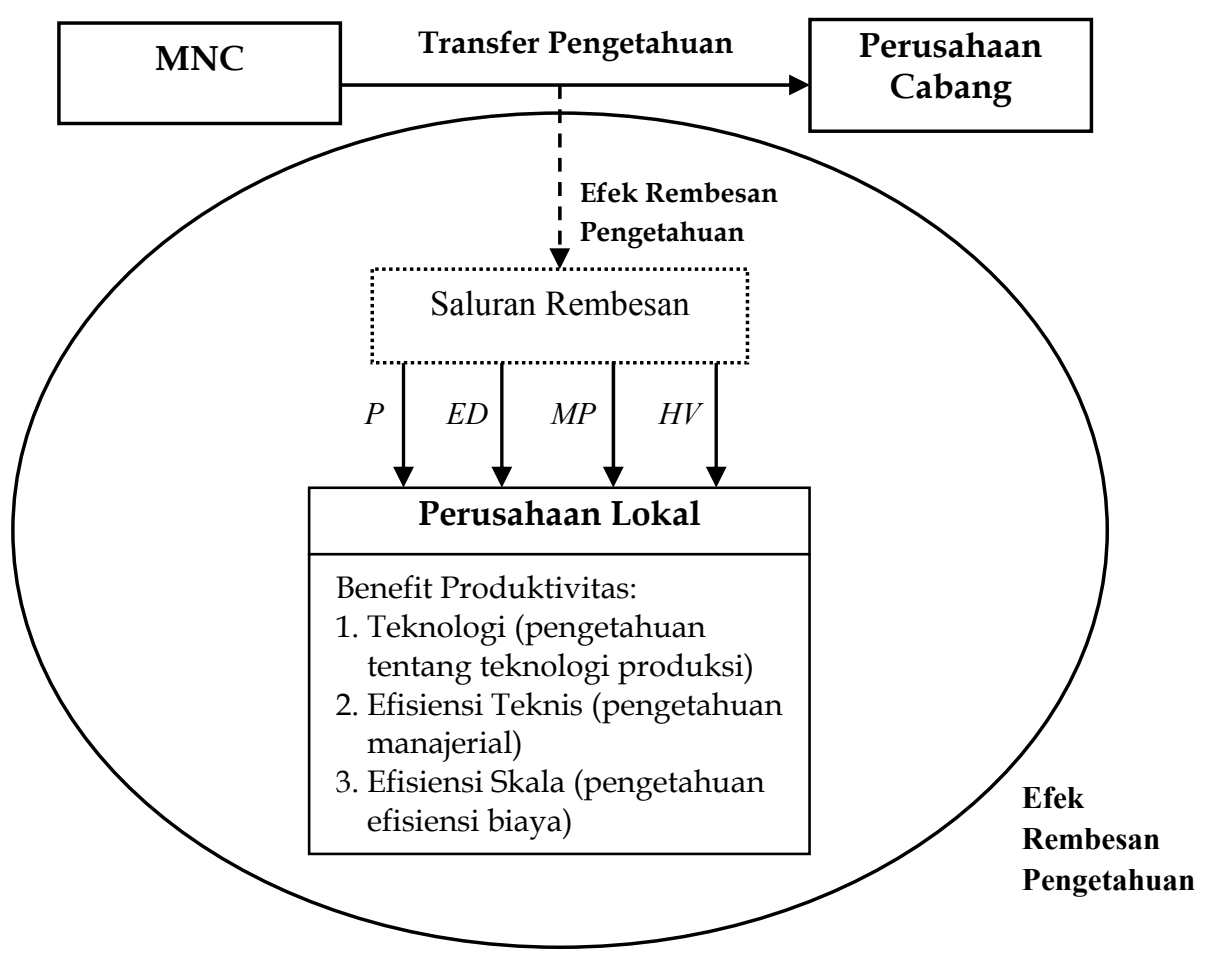

\begin{abstract}
Catatan: $P$ adalah persaingan, $E D$ is efek demonstrasi, $M P$ is mobilitas pekerja, and $\mathrm{HV}$ is hubungan vertikal industri

Sumber: Skema dibuat oleh penulis berdasarkan Gorg dan Greenaway (2004), Girma and Gorg (2007), Kravtsova and Zelenyuk (2007), Smeets (2008), dan Suyanto dan Salim (2010).
\end{abstract}

\title{
Gambar 1. Konsep Efek Rembesan dari PMA ke Produktivitas Perusahaan Lokal
}

tivitas. Tiga cara dapat ditempuh oleh perusahaan lokal untuk berkompetisi, yaitu: dengan memperkenalkan produk baru dengan memanfaatkan teknologi modern; menggunakan metode manajemen yang baru untuk meningkatkan efisiensi teknis; dan meningkatkan efisiensi skala untuk menekan biaya produksi (Gorg and Greenaway, 2004; Barry et al., 2005; Suyanto et al., 2012).

Efek demonstrasi terjadi ketika pengetahuan baru yang dipergunakan oleh perusahaan cabang MNC diadopsi oleh perusahaan lokal dalam bentuk inovasi produk dan inovasi manajemen (Javorcik, 2004). Efek demonstrasi terjadi dalam dua bentuk: bentuk langsung dan bentuk tidak langsung. Bentuk langsung terwujud ketika perusahaan lokal melakukan imitasi langsung terhadap pengetahuan baru yang dimiliki MNC. Bentuk tidak langsung terjadi ketika perusahaan lokal melakukan pengem- bangan inovasi baru melalui penelitian dan pengembangan (research and development).

Mobilitas pekerja dapat pula menjadi media rembesan pengetahuan ketika pekerja yang pernah dilatih oleh MNC pindah ke perusahaan lokal (Markusen and Trofimenko, 2007). MNC memainkan peran aktif dalam mengedukasi dan melatih pekerja lokal. Rembesan pengetahuan terjadi ketika pekerja ini pindah ke perusahaan lokal dan membawa beserta mereka pengetahuan MNC.

Hubungan vertikal industri juga merupakan media bagi rembesan pengetahuan. Ketika perusahaan lokal membeli dari pemasok asing (MNC suppliers), pengetahuan tentang bahan baku dan cara penggunaan bahan baku ditransferkan dari MNC ke perusahaan lokal, dan meningkatkan produktivitas. Proses rembesan pengetahuan ini dikenal sebagai backward spillovers (Suyanto et al., 2012). Sementara itu, rem- 
besan pengetahuan juga dapat terjadi dari pembeli asing (MNC buyers) ke perusahaan lokal, melalui standardisasi dan tuntutan kualitas (Javorcik, 2008). Pembeli asing seringkali menuntut standar kualitas tertentu untuk produk yang ingin dibeli. Tuntutan kualitas ini dapat menjadi pemicu perusahaan lokal untuk meningkatkan pengetahuannya tentang kualitas yang lebih tinggi dan berinovasi, sehingga produktivitas perusahaan lokal meningkat.

Dekomposisi produktivitas merupakan kontribusi penting dalam literatur PMA. Dengan metode dekomposisi ini, dapat diidentifikasi sumber peningkatan produktivitas perusahaan lokal dari keberadaan PMA, baik bersumber dari peningkatan efisiensi teknis atau kemajuan teknologi atau peningkatan skala efisiensi. Untuk peningkatan efisiensi teknis, intuisi yang mendasari adalah peningkatan daya saing (competition) terhadap MNC. Argumen ini konsisten dengan proses kompetisi yang dikemukakan oleh Chakraborty and Nunnenkamp, 2008). Untuk kemajuan teknologi, argumentasi didasarkan pada efek demonstrasi dan efek imitasi, yang sejalan dengan Havranek dan Irsova (2011). Sementara peningkatan skala efisiensi disebabkan oleh efek learning-by-doing, yang berhubungan dengan perpindahan pekerja level manajerial dari MNC ke perusahaan lokal (Markusen and Trofimenko, 2007).

Adanya efek rembesan pengetahuan dari MNC, produktivitas perusahaan lokal akan meningkat. Peningkatan produktivitas dapat di-dekomposisi menjadi tiga bagian penting, dalam literatur produktivitas (lihat misalnya: Coelli et al., 2005; Khumbakar dan Lovell, 2005). Ketiga bagian peningkatan produktivitas dikenal sebagai tiga sumber utama produktivitas, yaitu peningkatan efisiensi teknis (technical efficiency improvement), kemajuan teknologi (technological progress), dan peningkatan efisiensi skala (scale efficiency improvement). Peningkatan efisiensi teknis berhubungan langsung dari peningkatan output dengan input yang tertentu (ditinjau dari pendekatan output), atau penurunan input untuk menghasilkan output tertentu (ditinjau dari pendekatan input) (Coelli et al., 2005). Kemajuan teknologi berhubungan dengan peningkatan produktivitas karena per- geseran batas produksi (production frontier) dengan diperkenalkannya teknologi baru (Lee, 2006). Sedangkan peningkatan efisiensi skala berkaitan dengan skala produksi yang dimanfaatkan (Kravtzova and Zulenyuk, 2007).

Literatur empiris tentang produktivitas sangat jarang berfokus pada peningkatan produktivitas dari sisi efisiensi teknis dan efisiensi skala. Sebagian besar studi empiris menganalisis produktivitas dari sisi teknologi. Penggunaan fungsi produksi konvensional, yang umumnya digunakan oleh literatur produktivitas, hanya memungkinkan analisis pada kemajuan teknologi dikarenakan adanya asumsi dasar bahwa semua perusahaan berproduksi pada skala penuh dan dengan kombinasi input yang telah efisien. Sehingga, analisis produktivitas yang bersumber dari efisiensi teknis dan efisiensi skala seringkali terabaikan. Penelitian empiris untuk menganalisis ketiga sumber produktivitas menjadi perlu dan mendesak untuk dilakukan.Tulisan ini memberikan kontribusi signifikan dalam hal ini.

Di Indonesia, penelitian tentang dekomposisi produktivitas dari efek rembesan PMA belum banyak dilakukan. Suyanto et al. (2009) melakukan dekomposisi produktivitas menggunakan metode parametrik untuk industri farmasi (ISIC 35) dan memperlihatkan bahwa peningkatan produktivitas perusahaan lokal sebagian besar disebabkan oleh kemajuan teknologi. Peningkatan produktivitas yang bersumberkan dari kemajuan teknologi merupakan hal yang sejalan dengan sifat industri farmasi yang padat modal. Sementara, Suyanto dan Salim (2010) menggunakan metode nonparametrik dengan pendekatan Data Envelopment Analysis (DEA) untuk menganalisis industri yang lebih spesifik, yaitu industri makanan (ISIC 311) dan industri mesin elektrik (ISIC 383). Mereka menemukan bahwa peningkatan efisiensi teknis merupakan sumber utama peningkatan produktivitas di industri makanan, dan peningkatan teknologi merupakan sumber utama peningkatan produktivitas di industri mesin elektrik.

Dari studi-studi terdahulu ini, dapat disimpulkan bahwa industri yang berbeda akan memperoleh efek rembesan produktivitas yang 
berbeda. Karakteristik spesifik masing-masing industri secara signifikan akan mempengaruhi sumber peningkatan produktivitas dari efek rembesan PMA. Karena itu, kajian tentang efek rembesar produktivitas pada industri manufaktur Indonesia, secara keseluruhan, menjadi menarik. Sumber produktivitas yang penting menjadi berbeda, apabila keseluruhan perusahaan dalam industri manufaktur dimasukan sebagai objek analisis. Tentu saja, kajian menyeluruh ini akan menjadi komplementer bagi kajian-kajian terdahulu yang telah dilakukan terhadap industri yang spesifik.

Kajian menyeluruh memiliki kelebihan dalam memberikan gambaran umum dan holistik terhadap sumber peningkatan produktivitas di industri manufaktur Indonesia. Sementara, kajian terhadap industri spesifik memiliki kelebihan dalam memilah dampak yang dominan dari masing-masing sumber produktivitas. Karena itu, perlu kajian menyeluruh sebagai pelengkap kajian spesifik. Sehingga gambaran menyeluruh dan gambaran spesifik efek rembesan PMA terhadap produktivitas perusahaan lokal, dapat secara komprehensif dianalisis.

Studi empiris tentang peningkatan produktivitas dari PMA cukup banyak dijumpai dalam literature (studi yang terkenal di antaranya: Javorcik, 2005; Kugler, 2006; Liu, 2008; Havranek dan Irsova, 2011). Namun demikian, studi yang secara khusus menggunakan metode dekomposisi untuk menganalisis sumber peningkatan produktivitas masih sangat jarang ditemukan (di antaranya: Girma and Gorg, 2007; Kokko and Kratsova, 2008; Suyanto et al., 2009; Suyanto dan Salim, 2010).

Penggunaan fungsi produksi konvensional yang mengasumsikan bahwa perusahaan berproduksi pada skala produksi yang penuh, menjadi sebuah kendala bagi analisis sumber peningkatan produktivitas. Menurut Mahadevan (2003), asumsi ini sangat mengikat dan tidak sesuai dengan kenyataan. Di dunia nyata, perusahaan berproduksi pada skala yang tidak penuh dan pada tingkat efisiensi teknis yang tidak sempurna. Sehingga, peningkatan produktivitas tidak hanya tercermin dari kemajuan teknologi, tetapi juga dari peningkatan efisiensi teknis dan peningkatan efisiensi skala. Lee
(2006) juga berargumentasi serupa, bahwa penggunaan asumsi skala produksi penuh menyebabkan tidak bisa diukurnya peningkatan efisiensi teknis dan efisiensi skala. Sehingga, studi empiris tentang efek rembesan dari PMA yang menggunakan fungsi produksi konvensional hanya membatasi analisis pada kemajuan teknologi, dan mengabaikan peningkatan efisiensi teknis dan efisiensi skala.

Dengan berkembangnya waktu, para ahli produktivitas ekonomi mengembangkan model yang lebih memadai, yaitu fungsi produksi stokastik (stochastic production frontier). Fungsi produksi ini berbeda dengan fungsi produksi konvensional dalam hal, fungsi ini tidak menganalisis perilaku rata-rata (mean) dari perusahaan. Fungsi produksi stokastik menganalisis perilaku produksi perusahaan berdasarkan pada the best practice. Perusahaan dengan efisiensi produksi terbaik yang dijadikan sebagai batas (frontier) pembanding terhadap efisiensi produksi perusahaan lainnya. Selisih antara efisiensi produksi sebuah perusahaan dengan efisiensi produksi the best practice, disebut sebagai inefficiency (Lee, 2006). Adanya inefficiency ini memungkinkan diidentifikasikannya peningkatan efisiensi teknis (technical efficiency improvement) dan peningkatan efisiensi skala (scale efficiency enhancement).

Fungsi produksi stokastik ini dapat dipergunakan sebagai alternatif pengukuran sumber efek rembesan dari PMA. Dengan fungsi produksi ini, peningkatan produksi dapat didekomposisi menjadi tiga sumber: peningkatan efisiensi teknis, kemajuan teknologi, dan peningkatan efisiensi skala. Sehingga analisis dekomposisi dapat diaplikasikan.

Studi tentang efek rembesan PMA di industri manufaktur Indonesia telah dilakukan oleh beberapa peneliti. Takii (2005) merupakan salah satu studi yang pertama kali memanfaatkan panel data dalam kajian tentang pengaruh PMA terhadap produktivitas perusahaan lokal. Data yang dipergunakan dari 1990 sampai 1995. Dengan menggunakan model Transendental Logaritma (translog) dan memasukan efek waktu dan efek spesifik perusahaan, Takii menemukan bahwa terdapat efek rembesan positif dari PMA kepada perusahaan lokal yang 
berada di industri dengan ketimpangan teknologi kecil (small technological gap). Sementara industri dengan ketimpangan teknologi yang besar, perusahaan lokal mendapatkan efek negatif dari keberadaan PMA. Perusahaan lokal yang berada di industri dengan ketimpangan teknologi yang besar tidak mampu mengimitasi atau mengadopsi teknologi yang ada karena pengetahuan dan sumberdayanya yang kurang memadai.

Blalock dan Gertler (2005) memanfaatkan juga model translog dengan panel data analysis untuk menganalisis efek rembesan PMA di industri manufaktur Indonesia pada 1988 sampai 1996. Beda halnya dengan Takii (2005) yang menggunakan variabel dependen Value Added, Blalock dan Gertler menggunakan variabel dependen Output untuk mengevaluasi peningkatan produktivitas perusahaan lokal. Hal berbeda lainnya adalah variabel PMA yang dipergunakan dihitung dari proporsi kepemilikan asing sampai level ISIC 5 digit, sementara di Takii hanya menggunakan sampai level ISIC 3 digit. Hasil yang diperoleh dari studi Blalock dan Gertler ini adalah ditemukannya efek rembesan positif dari PMA di industri dengan kemampuan absorbsi yang tinggi. Ditemukan pula bahwa perusahaan dengan ketimpangan teknologi terkecil yang mendapatkan efek rembesan terkecil, kebalikan dari temuan Takii (2005).

Sementara itu, Todo dan Miyamoto (2006) lebih memilih menggunakan model CobbDouglas dan Semi Parametric untuk menganalisis peningkatan produktivitas yang disebabkan efek rembesan PMA. Mereka menemukan bahwa terdapat pengaruh positif keberadaan PMA dalam industri manufaktur Indonesia, dan pengaruh positif ini lebih dirasakan oleh perusahaan yang melakukan investasi dalam research and development (R\&D).

Jacob (2006) menggunakan data yang sama seperti Blalock dan Gertler (2005), tetapi menggunakan model yang berbeda, memperlihatkan bahwa kepemilikan asing memainkan peran penting dalam transfer teknologi. Meskipun studi Jacob (2006) tidak secara khusus membahas tentang efek rembesan dari PMA dan lebih fokus pada efek transfer teknologi langsung, penemuannya dapat dipergunakan sebagai indikasi adanya kemungkinan peningkatan produktivitas lokal dari adanya modal asing.

Blalock dan Gertler (2008) menambahkan efek rembesan dari pemasok (backward spillovers) ke dalam model dan menemukan bahwa terdapat pengaruh positif keberadaan PMA dalam industri hilir (pemasok) dalam peningkatan produktivitas perusahaaan lokal. Keberadaan PMA dalam industri yang sama, justru tidak memberikan efek rembesan terhadap produktivitas perusahaan lokal.

Suyanto et al. (2009) mengadopsi panel data stochastic production frontier untuk menganalisis peningkatan produktivitas perusahaan lokal dari keberadaan PMA di Industri Farmasi. Variabel baru yang dimasukkan dalam model adalah variabel persaingan. Data penelitian mencakup periode 1988 sampai 2000, yang lebih panjang daripada periode waktu studistudi sebelumnya. Ditemukan bahwa terdapat pengaruh positif keberadaan PMA di industri Farmasi Indonesia. Ditemukan pula bahwa persaingan meningkatkan efek rembesan positif dari PMA kepada perusahaan lokal. Selain itu, pengeluaran $R \& D$ meningkatkan kemampuan perusahaan untuk menyerap efek rembesan dari PMA, sehingga perusahaan lokal dengan $R \& D$ cenderung mendapatkan peningkatan produktivitas yang lebih besar daripada perusahaan lokal yang tidak melakukan R\&D.

Suyanto dan Salim (2010) menerapkan Data Envelopment Approach (DEA) dan Malmquist Productivity Index untuk menguji efek rembesan PMA ke perusahaan lokal dalam industri Makanan dan Industri Barang Elektrik. Mereka menemukan bahwa terdapat sumber produktivitas yang berbeda dari keberadaan PMA. Perusahaan lokal di industri Makanan cenderung mendapatkan efek rembesan bersumber dari peningkatan efisiensi, sedangkan perusahaan lokal pada industri Barang Elektrik cenderung mendapatkan efek rembesan yang bersumber dari kemajuan teknologi. Hal ini menguatkan argumen bahwa industri yang berbeda akan merespon berbeda terhadap keberadaan PMA.

Dari studi-studi terdahulu ini, dapatlah dinyatakan bahwa belum ada konsensus pasti 
antar peneliti tentang efek rembesan dari PMA kepada produktivitas perusahaan lokal. Sebagian besar memperlihatkan bahwa terdapat efek rembesan positif. Namun, beberapa penelitian, seperti Blalock dan Gertler (2008) memperlihatkan bahwa tidak ada efek rembesan dari PMA terhadap produktivitas perusahaan lokal di Industri sejenis (horizontal spillovers). Efek rembesan lebih kuat ditemukan dari perusahaan PMA yang memasok barang kepada perusahaan lokal (backward spillovers). Begitu pula, Suyanto et al. (2012) memperlihatkan bahwa efek rembesan PMA di industri garmen berbeda dengan di industri elektronik. Belum adanya konsensus ini dapat menjadi sebuah kesempatan bagi studi baru yang mengkaji isu terkait. Karena itu, studi ini berusaha mengkaji efek rembesan PMA dengan cara men-dekomposisi pertumbuhan produktivitas menjadi tiga sumber: peningkatan efisiensi teknis, kemajuan teknologi, dan peningkatan efisiensi skala. Diharapkan dengan studi baru ini, dapat diketahui sumber efek rembesan PMA di industri manufaktur Indonesia.

Tulisan ini mengkaji secara empiris manfaat produktivitas di perusahaan-perusahaan manufaktur Indonesia, dari 1988 sampai 2000. Dengan mengkombinasikan rerangka teoretis yang dikembangkan oleh Orea (2002) dan Coelli et al. (2005), penelitian ini mendekomposisi pertumbuhan Total Faktor Productivity Growth (TFPG) menjadi tiga komponen tersebut di atas. Kontribusi penting yang diberikan oleh tulisan ini terbagi atas tiga, yaitu: (1) mengadaptasikan metode dalam literatur produktivitas dalam menyelesaikan isu di literatur PMA, sehingga terjadi pengkombinasian dua bidang literatur yang berbeda tetapi saling menyempurnakan satu dengan lainnya; (2) menganalisis TFPG dari sisi kemajuan teknologi dan efisiensi, sehingga tidak hanya terbatas pada analisis dari sisi kemajuan teknologi saja, seperti yang umumnya dilakukan oleh literatur terdahulu; (3) menggunakan data survei perusahaan yang lengkap dan komprehensi yang telah dilakukan oleh BPS melalui survei tahunan.

\section{METODE PENELITIAN}

\section{Metode Analisis}

Metode analisis yang dipergunakan dalam penelitian ini mengadopsi model dekomposisi TFP berdasarkan pendekatan Stochastic Production Frontier. Dua langkah dipergunakan dalam model dekomposisi ini, dengan penjelasan sebagai berikut:

Langkah Pertama: Formulasi persamaan distance function dengan menggunakan fungsi produksi translog, dengan variabel dependen adalah output dan variabel-variabel independen adalah tenaga kerja, modal, dan bahan baku. Variabel PMA dipergunakan sebagai variabel yang mempengaruhi efisiensi, yang diestimasi secara simultan dengan fungsi produksi translog. Kedua fungsi dapat dituliskan sebagai berikut:

Fungsi produksi translog:

$$
\begin{gathered}
\ln y_{i t}=\alpha_{0}+\sum_{n=1}^{N} \alpha_{n} \ln x_{n i t}+\frac{1}{2} \sum_{n=1}^{N} \sum_{k=1}^{N} \alpha_{n k} \ln x_{n i t} \ln x_{k i t}+ \\
\alpha_{t} t+\frac{1}{2} \alpha_{t t} t^{2}+\sum_{n=1}^{N} \alpha_{n t} \ln x_{n i t} t+v_{i t}-u_{i t}
\end{gathered}
$$

Fungsi inefisiensi:

$$
u_{i t}=\delta_{0}+\sum_{j=1}^{J} \delta_{j} z_{j i t}+w_{i t}
$$

Untuk $y_{i t}$ mewakili produksi perusahaan ke-i pada tahun ke-t; $x_{\text {nit }}$ adalah faktor produksi ke-n pada perusahaan ke-i di tahun ke-t; a adalah parameter yang perlu diestimasi; $\mathrm{t}$ adalah tahun; $\mathrm{u}$ adalah variabel inefisiensi teknis; $\mathrm{v}$ adalah variabel stokastik untuk fungsi produksi; Z adalah variabel yang mempengaruhi inefisiensi teknis, salah satunya adalah PMA; w adalah error-term atau variabel random yang tidak terobservasi.

Kedua persamaan diestimasi secara simultan dengan menggunakan metode Battese dan Coelli (1995) untuk mengetahui pengaruh PMA terhadap efisiensi dan produktivitas. Hasil estimasi simultas persamaan (1) dan (2) akan menghasilkan efisiensi teknis (technical efficiency, TE) berikut: 


$$
\begin{array}{r}
T E=\frac{\ln y_{i t}}{\ln y_{i t}^{p}}=E\left[-u_{i t} \mid\left(v_{i t}-u_{i t}\right)\right]= \\
E\left[\left(-z_{i t} \delta-w_{i t}\right)\left(v_{i t}-u_{i t}\right)\right]
\end{array}
$$

untuk

$$
\begin{aligned}
\ln y_{i t}^{p}= & {\left[\alpha_{0}+\sum_{n=1}^{N} \alpha_{n} \ln x_{n i t}+\frac{1}{2} \sum_{n=1}^{N} \sum_{k=1}^{K} \alpha_{n k} \ln x_{n i t} \ln x_{k i t}+\right.} \\
& \left.\alpha_{t} t+\frac{1}{2} \alpha_{t t} t^{2}+\sum_{n=1}^{N} \alpha_{n t} \ln x_{n i t} t+v_{i t}\right]
\end{aligned}
$$

Translog Distance function untuk fungsi produksi pada persamaan (1) di atas adalah:

$$
\begin{aligned}
\ln D_{0}\left(y_{i t}, x_{i t}, t\right) & =\alpha_{0}+\sum_{n=1}^{N} \alpha_{n} \ln x_{n i t}+ \\
& \frac{1}{2} \sum_{n=1}^{N} \sum_{k=1}^{N} \alpha_{n k} \ln x_{n i t} \ln x_{k i t}+ \\
& \alpha_{t} t+\frac{1}{2} \alpha_{t t} t^{2}+\sum_{n=1}^{N} \alpha_{n t} \ln x_{n i t} t
\end{aligned}
$$

Perusahaan yang terletak pada distance function ini yang merupakan the best-practice, yang dipergunakan sebagai acuan perbandingan dengan masing-masing perusahaan yang diobservasi.

Langkah Kedua: Dari distance function persamaan (5) kemudian dihitung TFP growth dengan menggunakan metode dekomposisi Malmquist Productivity Index (MPI) parametric yang perkenalkan Oreo (2002). Berdasarkan metode ini, TFP growth (TFPG) didekomposisi sebagai berikut:

$$
T F P G_{O i}^{t, t+1}=T E C_{i}^{t, t+1}+T P_{i}^{t, t+1}+S E C_{i}^{t, t+1}
$$

untuk

$$
\begin{gathered}
T E C_{i}^{t, t+1}=\ln D_{O}\left(y_{i, t+1}, x_{i, t+1}, t+1\right)-\ln D_{O}\left(y_{i t}, x_{i t}, t\right) \\
T P_{i}^{t, t+1}=\frac{1}{2}\left[\frac{\partial \ln D_{O}\left(y_{i, t+1}, x_{i, t+1}, t+1\right)}{\partial(t+1)}+\frac{\partial \ln D_{O}\left(y_{i t}, x_{i t}, t\right)}{\partial t}\right]
\end{gathered}
$$

$S E C_{i}^{t, t+1}=\frac{1}{2} \sum_{n=1}^{N}\left[\frac{\varepsilon_{i, t+1}-1}{\varepsilon_{i, t+1}} \varepsilon_{i, t+1, n}+\frac{\varepsilon_{i t}-1}{\varepsilon_{i t}} \varepsilon_{i t n}\right] \cdot \ln \left[\frac{x_{i, t+1, n}}{x_{i t n}}\right]_{(9)}$

dengan $\varepsilon_{i t}=\sum_{n=1}^{N} \varepsilon_{i t n}$ adalah scale elasticity

dengan $\varepsilon_{i t n}=\frac{\partial \ln D_{O}\left(y_{i t}, x_{i t}, t\right)}{\partial \ln x_{i t n}}$.

Simbol TEC mewakili technical efficiency change, yang dipergunakan untuk mengukur perubahan efisiensi teknis antar waktu untuk masing-masing perusahaan. Simbol TP dipergunakan untuk mewakili technological progress, yang menunjukkan kemajuan teknologi masing-masing perusahaan antarwaktu. SEC merupakan simbol dari scale efficiency change, yaitu perubahan efisiensi skala.

Dengan efisiensi teknis seperti didefinisikan pada persamaan (3) dan distance function seperti pada persamaan (5), TEC pada persamaan (7) dapat dituliskan ulang menjadi:

$T E C_{i}^{t, t+1}=\ln T E_{i, t+1}-\ln T E_{i t}$

TP pada persamaan (8) dapat dihitung dari persamaan (4), (5), dan (8) sebagai berikut:

$$
\begin{aligned}
T P_{i, t+1, t}= & \frac{1}{2}\left[\sum_{n=1}^{N} \alpha_{t n} \ln x_{i, t+1, n}+\sum_{n=1}^{N} \alpha_{t n} \ln x_{i t n}+\right. \\
& \left.2 \alpha_{t}+\alpha_{t t}[(t+1)+t]\right]
\end{aligned}
$$

Dari persamaan (1), scale elasticity dapat dituliskan menjadi:

$$
\varepsilon_{n i t}=\alpha_{n}+\frac{1}{2} \sum_{k=1}^{K} \alpha_{n k} x_{n i t}+\alpha_{n t} t
$$

Nilai SEC persamaan (9) dapat dihitung dari scale elasticity pada persamaan (12).

\section{Data dan Variabel}

Data utama yang dipergunakan dalam penelitian ini diperoleh dari Survei Perusahaan Industri Menengah dan Besar yang dilakukan setiap tahun oleh Badan Pusat Statistik (BPS). Survei ini telah dilakukan oleh BPS sejak 1970. 
Jumlah perusahaan yang disurvei bervariasi, mulai dari 7.469 perusahaan di tahun 1970 sampai 24.469 perusahaan di tahun 2009. Perusahaan manufaktur yang menjadi target survei ini adalah perusahaan dengan jumlah tenaga kerja 25 orang atau lebih. Variabel yang tercakup dalam data survei ini sangat lengkap, mencakup lokasi perusahaan (kecamatan, kabupaten, provinsi), komposisi kepemilikan (pemerintah pusat, pemerintah daerah, swasta, dan asing), produksi (output dan nilai tambah), bahan baku (bahan utama dan bahan penolong), tenaga kerja (tetap dan paruh waktu, pria dan wanita, tingkat pendidikan pekerja), modal (nilai taksiran pembentukan modal), energi (pemakaian listrik dan bahan bakar), pengeluaran untuk pelatihan dan pengembangan, dan lain sebagainya. Masing-masing perusahaan diberikan kode PSID untuk identifikasi perusahaan, sehingga memungkinkan data panel (gabungan antara runtut-waktu dan silangruang). Data tersedia dan dipublikasi oleh BPS dalam bentuk d-base. Sampai saat tulisan ini dibuat, data yang tersedia adalah dari tahun 1970 sampai 2009. Namun demikian, data yang dipergunakan adalah 1988 sampai 2000. Sebelum 1988, tidak ada informasi tentang modal dalam survei yang dilakukan, sehingga data 1970 sampai 1987 dikeluarkan dari analisis. Sementara, terjadi perubahan kode spesifik perusahaan di tahun 2002 tanpa ada tabel konversi dari BPS, sehingga tidak memungkinkan dimasukannya periode 2002-2009 dalam analisis. Sedangkan tahun 2001 dikeluarkan dari observasi karena menurunkan jumlah perusahaan menjadi hanya 50 persen ketika balanced panel data dilakukan. Sehingga, data yang dipergunakan dalam penelitian ini mencakup periode 19882000, untuk sebanyak 3.318 perusahaan (total observasi: 43.134).

Data tambahan berupa Index Harga Pedagang Besar (IHPB) diperoleh dari Statistik Industri yang dipublikasikan oleh BPS. Data lain berupa Index Harga Bahan Bakar (IHBB) dihitung dari harga bahan bakar yang dipublikasikan oleh Departemen Energi dan Sumberdaya Mineral secara online di website www.esdm. go.id. IHPB dipergunakan sebagai deflator untuk variabel output, material, dan modal. IHBB dipergunakan sebagai deflator untuk variabel energi.

Tabel 1 memperlihatkan definisi operasional masing-masing variabel yang dipergunakan.

Tabel 1. Variabel dan Definisi Operasional

\begin{tabular}{|c|c|}
\hline Variabel & Definisi \\
\hline $\mathrm{Y}$ & $\begin{array}{l}\text { Output (dalam jutaan rupiah), yang } \\
\text { dideflasikan dengan indeks harga pe- } \\
\text { dagang besar pada tingkat ISIC 4-digit } \\
\text { dengan harga konstan } 1993\end{array}$ \\
\hline $\mathrm{L}$ & Tenaga kerja (dalam jumlah orang) \\
\hline K & $\begin{array}{l}\text { Modal (jutaan rupiah), yang didefla- } \\
\text { sikan dengan indeks harga pedagang } \\
\text { besar pada tingkat ISIC 4-digit dengan } \\
\text { harga konstan } 1993\end{array}$ \\
\hline M & $\begin{array}{l}\text { Bahan baku (dalam jutaan rupiah), yang } \\
\text { dideflasikan dengan indeks harga peda- } \\
\text { gang besar pada tingkat ISIC 4-digit } \\
\text { dengan harga konstan } 1993\end{array}$ \\
\hline $\mathrm{E}$ & $\begin{array}{l}\text { Energi (jutaan rupiah), dijumlahkan } \\
\text { dari pengeluaran untuk listrik dan pe- } \\
\text { ngeluaran untuk bahan bakar. Didefla- } \\
\text { sikan dengan indeks harga pedagang } \\
\text { besar untuk listrik dan dideflasikan de- } \\
\text { ngan indeks harga bahan bakar untuk } \\
\text { bahan bakar. Harga konstan } 1993 \text {. }\end{array}$ \\
\hline $\mathrm{t}$ & $\begin{array}{l}\text { Waktu, diberikan nilai } 1 \text { untuk tahun } \\
\text { 1988, nilai } 2 \text { untuk tahun 1989, dan } \\
\text { seterusnya. }\end{array}$ \\
\hline PMA & $\begin{array}{l}\text { Kepemilikan asing, diukur dengan } \\
\text { variabel dummy: } 1 \text { jika perusahaan } \\
\text { memiliki kepemilikan asing, } 0 \text { apabila } \\
\text { perusahaan tidak memiliki kepemilikan } \\
\text { asing. }\end{array}$ \\
\hline Spillover & $\begin{array}{l}\text { Variabel spillover yang dipergunakan } \\
\text { untuk mengukur efek rembesan PMA } \\
\text { ke perusahaan lokal. Diukur dari pro- } \\
\text { porsi output perusahaan asing terhadap } \\
\text { total output di industri ISIC 3-digit. }\end{array}$ \\
\hline Age & $\begin{array}{l}\text { Usia perusahaan, dihitung dari selisih } \\
\text { antara tahun survei dan tahun berdiri. }\end{array}$ \\
\hline Krisis & $\begin{array}{l}\text { Variabel krisis, dipergunakan untuk } \\
\text { menetralisir efek krisis yang terjadi } \\
\text { pada 1997. Bernilai } 1 \text { untuk tahun } 1997 \\
\text { ke atas dan bernilai } 0 \text { untuk tahun } \\
\text { sebelum 1997. }\end{array}$ \\
\hline
\end{tabular}




\section{Model Empiris}

Dari model umum translog pada persamaan (1) dan (2) dapat diturunkan model empiris untuk penelitian ini, berdasarkan pemilihan variabel pada Tabel 1, sebagai berikut:

$$
\begin{aligned}
\ln y_{i t}= & \alpha_{0}+\alpha_{L} \ln L_{i t}+\alpha_{K} \ln K_{i t}+\alpha_{M} \ln M_{i t}+\alpha_{E} \ln E_{i t}+ \\
& \alpha_{L E}\left[\ln L_{i t}\right]^{2}+\alpha_{L K}\left[\ln L_{i t} * \ln K_{i t}\right]+ \\
& \alpha_{L M}\left[\ln L_{i t} * \ln M_{i t}\right]+\alpha_{L E}\left[\ln L_{i t} * \ln E_{i t}\right]+ \\
& \alpha_{K K}\left[\ln K_{i t}\right]^{2}+\alpha_{K M}\left[\ln K_{i t} * \ln M_{i t}\right]+ \\
& \alpha_{K E}\left[\ln K_{i t} * \ln E_{i t}\right]+\alpha_{M M}\left[\ln M_{i t}\right]^{2}+ \\
& \alpha_{M E}\left[\ln M_{i t} * \ln E_{i t}\right]+\alpha_{E E}\left[\ln E_{i t}\right]^{2}+\alpha_{t} t+ \\
& \alpha_{L t}\left[\ln L_{i t} * t\right]+\alpha_{K t}\left[\ln K_{i t} * t\right]+\alpha_{M t}\left[\ln M_{i t} * t\right]+ \\
& \alpha_{E t}\left[\ln E_{i t} * t\right]+\alpha_{t t} t^{2}+v_{i t}-u_{i t}
\end{aligned}
$$

$$
\begin{gathered}
u_{i t}=\delta_{0}+\delta_{1} P M A_{i t}+\delta_{2} \text { Spillover }_{i t}+ \\
\delta_{3} A G E_{i t}+\delta_{4} \text { CRISIS }_{i t}+w_{i t}
\end{gathered}
$$

untuk $y$ adalah output, $L$ adalah tenaga kerja, $K$ adalah modal, $\boldsymbol{M}$ adalah bahan baku, $\boldsymbol{E}$ adalah energi, $\boldsymbol{t}$ adalah waktu, $\boldsymbol{v}$ adalah komponen error-term yang stochastic dan time-specific, $\boldsymbol{u}$ adalah komponen error-term yang mewakili technical inefficiency, PMA adalah variabel dummy yang mewakili kepemilikan asing, spillover adalah variabel efek rembesan PMA terhadap efisiensi dan produktivitas perusahaan local, AGE adalah usia perusahaan, CRISIS adalah variabel dummy untuk krisis ekonomi 1997.

Model empiris pada persamaan (13) dan persamaan (14) diestimasi secara simultan dengan menggunakan metode Stochastic Production Frontier umtuk data panel yang diperkenalkan oleh Battese dan Coelli (1995). Dari hasil estimasi tersebut, dihitung efisiensi teknis seperti pada persamaan (3). Perolehan efisiensi teknis dan hasil estimasi terhadap parameter persamaan (13) dan persamaan (14) dipergunakan untuk menghitung TFPG, technical efficiency change (TEC), technological progress (TP), dan scale efficiency change (SEC) dengan menurunkan model empiris dari persamaan (6), (7), (8), dan
(9), sehingga diperoleh persamaan berikut:

$$
T E C_{i}^{t, t+1}=\ln T E_{i}^{t+1}-\ln T E_{i}^{t}
$$

$$
\begin{gathered}
T C_{i, t+1, t}=\frac{1}{2}\left\{\begin{array}{l}
2 \alpha_{t}+\alpha_{L t}\left(\ln L_{i, t+1}+\ln L_{i t}\right)+ \\
\alpha_{K t}\left(\ln K_{i, t+1}+\ln K_{i t}\right)+ \\
\alpha_{M t}\left(\ln M_{i, t+1}+\ln M_{i t}\right)+ \\
\alpha_{E t}\left(\ln E_{i, t+1}+\ln E_{i t}\right)+ \\
\alpha_{t t}((t+1)+t)
\end{array}\right] \\
S E C_{i}^{t, t+1}=\frac{1}{2}\left\{\begin{array}{l}
{\left[\begin{array}{l}
{\left[\frac{\varepsilon_{i, t+1}-1}{\varepsilon_{i, t+1}} \varepsilon_{i, t+1, L}+\frac{\varepsilon_{i t}-1}{\varepsilon_{i t}} \varepsilon_{i t L}\right] \cdot\left[\frac{\ln L_{i, t+1}}{\ln L_{i t}}\right]+} \\
{\left[\frac{\varepsilon_{i, t+1}-1}{\varepsilon_{i, t+1}} \varepsilon_{i, t+1, K}+\frac{\varepsilon_{i t}-1}{\varepsilon_{i t}} \varepsilon_{i t K}\right] \cdot\left[\frac{\ln K_{i, t+1}}{\ln K_{i t}}\right]+} \\
{\left[\frac{\varepsilon_{i, t+1}-1}{\varepsilon_{i, t+1}} \varepsilon_{i, t+1, M}+\frac{\varepsilon_{i t}-1}{\varepsilon_{i t}} \varepsilon_{i t M}\right] \cdot\left[\frac{\ln M_{i, t+1}}{\ln M_{i t}}\right]+} \\
{\left[\frac{\varepsilon_{i, t+1}-1}{\varepsilon_{i, t+}} \varepsilon_{i, t+1, E}+\frac{\varepsilon_{i t}-1}{\varepsilon_{i t}} \varepsilon_{i t E}\right] \cdot\left[\frac{\ln E_{i, t+1}}{\ln E_{i t}}\right]}
\end{array}\right\}}
\end{array}\right.
\end{gathered}
$$

untuk $T E_{i}^{t}$ dan $T E_{i}^{t+1}$ adalah efisiensi teknis untuk perusahaan i pada periode $\mathrm{t}$ dan periode $\mathrm{t}+1$, yang dihitung dari persamaan (3), dan $\varepsilon_{i t}=\varepsilon_{i t L}+\varepsilon_{i t K}+\varepsilon_{i t M}+\varepsilon_{i t E}$ adalah penjumlahan elastisitas skala untuk semua input., sehingga

$\varepsilon_{i t L}=\frac{\partial \ln y_{i t}}{\partial \ln L_{i t}}, \varepsilon_{i t K}=\frac{\partial \ln y_{i t}}{\partial \ln K_{i t}}$,

$\varepsilon_{i t M}=\frac{\partial \ln y_{i t}}{\partial \ln M_{i t}}$, dan $\varepsilon_{i t E}=\frac{\partial \ln y_{i t}}{\partial \ln E_{i t}}$

\section{HASIL DAN PEMBAHASAN}

\section{Sekilas tentang Industri Manufaktur Indonesia}

Industri Manufaktur Indonesia merupakan salah satu industri dengan pertumbuhan tinggi sejak akhir 1970-an. Pertumbuhan industri ini bahkan melampaui sektor pertanian sejak akhir 
1980-an, dengan pertumbuhan mencapai 22,05 persen di tahun 1984. Dengan pertumbuhan tinggi, output dan lapangan kerja di industri ini semakin meningkat. Begitu pula, akumulasi modal dan perluasan industrialisasi menjadi pencapaian industri manufaktur.

Pertumbuhan pesat industri ini tidak terlepas dari kebijakan perdagangan dan investasi yang dijalankan pemerintah. Liberalisasi perdagangan pada pertengahan 1980-an mendorong pesat pertumbuhan industri manufaktur. Penurunan tarif, penghapusan halangan nontarif, privatisasi sejumlah perusahaan milik negara, dan dihapuskannya halangan PMA, mendorong penuh industri ini bergerak dengan kecepatan dan percepatan yang tinggi (Adiningsih et al., 2009). Reformasi sektor fiskal dan keuangan, pengadopsian sistem nilai tukar fleksibel yang realistis, dan pengurangan intervensi pemerintah dalam perusahaan milik negara menjadikan industri manufaktur sebagai sektor yang dilirik oleh penanam modal asing dan pelaku perdagangan internasional (Thee, 2006; Syamsudin dan Setyawan, 2008). Kebijakan pengembangan industri yang berfokus pada industri yang menjadi prioritas dan penciptaan zona industri khusus, menjadikan pengembangan industri manufaktur semakin kencang (Ikhsan, 2007).

Perubahan arah kebijakan perdagangan dari intervensi ke liberalisasi mendorong ekspansi sub-sektor industri manufaktur yang berorientasi ekspor. Sub-sektor seperti Kimia dan Farmasi, Kayu dan Produk Kayu, Karet dan Produk Karet, menjadi semakin bertumbuh dengan adanya perubahan arah kebijakan ini. Sehingga, ekspor industri manufaktur meningkat tajam sejak 1987. Sebagai contoh, antara 1987 sampai 1993, ekspor industri manufaktur bertumbuh rata-rata 27 persen per tahun (BI, 2009). Perusahaan-perusahaan ekspor mencapai pertumbuhan yang lebih tinggi daripada perusahaan-perusahaan non-ekspor, dan pada waktu yang sama, perusahaan-perusahaan tersebut mencapai pertumbuhan produktivitas yang tinggi.

Tingginya peningkatan produktivitas sektor manufaktur terlihat dari meningkatnya Total Factor Productivity (TFP) selama periode libe- ralisasi. Pada periode 1981-1983, pertumbuhan TFP sektor manufaktur Indonesia adalah negatif, tepatnya $-4,9$ persen per tahun (Ikhsan, 2007). Pertumbuhan ini meningkat menjadi positif, dan bahkan pada periode setelah liberalisasi pertumbuhan TFP mencapai 6 persen per tahun (Vial, 2006).

Salah satu faktor penting yang mempengaruhi pertumbuhan TFP yang luarbiasa di sektor manufaktur periode setelah liberalisasi adalah penanaman modal asing (PMA). Peningkatan tinggi jumlah PMA netto yang masuk ke Indonesia meningkat pesat dari hanya US $\$ 0,2$ milyar di tahun 1983, menjadi US\$5,9 milyar di tahun 2006. Peningkatan besar ini mendorong pertumbuhan yang spektakular sektor manufaktur, sehingga menjadi "mesin penggerak" perekonomian sejak pertengahan 1980-an sampai dewasa ini. Peningkatan aliran masuk PMA berkontribusi terhadap output, lapangan kerja, dan nilai tambah sektor manufaktur. Selain itu, aliran masuk PMA ini juga menciptakan rantai industri yang semakin baik, baik industri hulu maupun industri hilir, sehingga tercipta backward dan forward linkages.

Aliran PMA yang besar ke sektor manufaktur dapat dilihat dari besarnya proporsi PMA sektor ini terhadap total PMA yang masuk. Secara umum, proporsi PMA sektor manufaktur yg disetujui oleh Badan Koordinasi Penanaman Modal (BKPM) adalah sebesar lebih dari 50 persen dari total PMA Indonesia selama tiga dekade belakangan ini (Suyanto, et al. 2009). Sebagai contoh, selama 1975-1979, proporsi PMA sektor manufaktur mencapai 68,89 persen dari total PMA di Indonesia. Pada periode liberalisasi perdagangan, 1984-1989, persentase PMA manufaktur terhadap total PMA Indonesia mencapai 82,52 persen. Bahkan di tahun 2000-2004, PMA manufaktur mencapai 55,20 persen dari total PMA. Tabel 2 memperlihatkan proporsi PMA sektor manufaktur terhadap total PMA di Indonesia selama tiga dekade terakhir.

Tingginya proporsi PMA di sektor manufaktur menjadi salah satu pertimbangan diperlukannya studi tentang benefit PMA bagi sektor ini. Secara makroekonomi, masuknya PMA ke sektor manufaktur akan meningkatkan akumu- 
Tabel 2. Proporsi PMA Sektor Manufaktur 1975-2009

\begin{tabular}{cccc}
\hline Tahun & $\begin{array}{c}\text { Total PMA Disetujui } \\
\text { (juta US\$) }\end{array}$ & $\begin{array}{c}\text { PMA Manufaktur } \\
\text { Disetujui (juta US\$) }\end{array}$ & $\begin{array}{c}\text { Proporsi PMA Manufaktur } \\
\text { terhadap Total PMA (persentase) }\end{array}$ \\
\hline $1975-1979$ & $5.322,10$ & $3.666,40$ & 68,89 \\
$1980-1984$ & $7.765,70$ & $6.346,10$ & 81,72 \\
$1985-1989$ & $12.300,20$ & $10.150,10$ & 82,52 \\
$1990-1994$ & $57.996,50$ & $37.507,10$ & 64,67 \\
$1995-1999$ & $126.919,20$ & $81.092,60$ & 63,89 \\
$2000-2004$ & $57.495,20$ & $31.735,20$ & 55,20 \\
$2005-2009$ & $54.068,20$ & $22.067,10$ & 40,81 \\
\hline $1975-2009$ & $321.867,10$ & $192.564,60$ & 59,83 \\
\hline
\end{tabular}

Sumber: Diolah dari Statistik Ekonomi dan Keuangan Indonesia, berbagai tahun.

lasi modal dan penciptaan lapangan kerja. Namun demikian, manfaat yang lebih bersifat jangka panjang adalah peningkatan produktivitas perusahaan-perusahaan dalam industri manufaktur tersebut, dengan keberadaan PMA. Manfaat produktivitas seperti ini dapat diidentifikasi secara tidak langsung dari efek rembesan (spillovers), yang menjadi fokus dalam penelitian ini.

\section{Estimasi Frontier Produksi Stokastik}

Dengan mengestimasi persamaan (13) dan persamaan (14), diperoleh hasil pengolahan data seperti pada Tabel 3. Estimasi dilakukan terhadap tiga kelompok data: total perusahaan dalam observasi, hanya perusahaan lokal, dan hanya perusahaan asing. Hasil setimasi untuk total perusahaan yang diobservasi ditampilkan pada kolom kedua Tabel 3. Sementara, hasil estimasi untuk sample hanya perusahaan lokal, ditampilkan pada kolom ketiga Tabel 4. Begitu pula, hasil estimasi untuk sampel hanya perusahaan asing ditampilkan pada kolom keempat Tabel yang sama. Tujuan dilakukannya estimasi untuk ketiga kelompok adalah (1) untuk mengetahui dampak PMA terhadap efisiensi dan produktivitas seluruh perusahaan dalam sampel, (2) untuk mengetahui dampak PMA terhadap efisiensi dan produktivitas pada perusahaan lokal saja dan dampak pada perusahaan asing saja, (3) untuk memperbandingkan efek rembesan PMA terhadap perusahaan lokal dan terhadap perusahaan asing.

Mari kita mulai dari hasil estimasi untuk data observasi keseluruhan, seperti pada kolom kedua Tabel 3. Dari frontier produksi stokastik diperoleh bahwa variabel input tenaga kerja (lnL) memiliki pengaruh yang signifikan terhadap output pada tingkat signifikansi 99 persen. Begitu pula variabel input modal $(\operatorname{lnK})$ memiliki pengaruh signifikan terhadap output yada tingkat signifikansi 99 persen. Pengaruh signifikansi yang sama juga dapat ditemukan pada variabel input bahan baku $(\operatorname{lnM})$ dan variabel input energi (lnE). Variabel pangkat dua untuk tenaga kerja $[\operatorname{lnL}] 2$ dan variabel pangkat dua untuk modal $[\operatorname{lnK}] 2$ signifikan pada tingkat signifikansi 95 persen, sedangkan variabel pangkat dua untuk bahan baku [lnM]2 dan variabel pangkat dua untuk energi [ $\ln E] 2$ signifikan pada tingkat signifikansi 99 persen. Variabel interaksi antarinput, antara lain $\left[\ln L^{*} \ln K\right], \quad\left[\ln L^{*} \ln \mathrm{M}\right], \quad\left[\ln L^{*} \ln E\right], \quad\left[\ln K^{*} \ln \mathrm{M}\right]$, $\left[\ln K^{*} \ln E\right], \quad\left[\ln M^{*} \ln E\right], \quad$ memiliki pengaruh signifikansi yang tinggi pada 99 persen. Hal yang cukup mengejutkan ditemukan pada variabel interaksi input dengan waktu, antara lain $\left[\ln L^{*} \mathrm{~T}\right],\left[\ln K^{*} \mathrm{~T}\right],\left[\ln E^{*} \mathrm{~T}\right]$, tidak signifikan secara statistik, walaupun variabel interaksi input bahan baku dan waktu [lnM*T] signifikan pada tingkat yang rendah, yaitu 90 persen. Hal ini mengindikasikan bahwa perubahan input antarwaktu tidak berpengaruh secara signifikan 
Tabel 3: Hasil Estimasi Frontier Produksi Stokastik

\begin{tabular}{|c|c|c|c|}
\hline Variabel & Semua Perusahaan & Perusahaan Lokal & Perusahaan Asing \\
\hline \multicolumn{4}{|c|}{ Fungsi Produksi Stokastik } \\
\hline \multirow{2}{*}{ Konstanta } & $1,144^{* * *}$ & $1,128^{* * *}$ & $0,468^{*}$ \\
\hline & $(37,08)$ & $(34,42)$ & $(1,66)$ \\
\hline \multirow[t]{2}{*}{$\ln L$} & $0,601^{* * *}$ & $0,595^{* * *}$ & $0,315^{* * *}$ \\
\hline & $(32,87)$ & $(28,85)$ & $(2,97)$ \\
\hline \multirow[t]{2}{*}{$\ln K$} & $0,180^{* * *}$ & $0,197^{* * *}$ & $0,186^{* * *}$ \\
\hline & $(17,34)$ & $(17,42)$ & $(2,63)$ \\
\hline \multirow[t]{2}{*}{$\ln M$} & $0,212^{* * *}$ & $0,175^{* * *}$ & $0,616^{* * *}$ \\
\hline & $(19,41)$ & $(15,27)$ & $(8,22)$ \\
\hline \multirow[t]{2}{*}{$\ln E$} & $0,244^{* * *}$ & $0,263^{* * *}$ & $0,285^{\star * *}$ \\
\hline & $(26,16)$ & $(27,79)$ & $(3,66)$ \\
\hline \multirow[t]{2}{*}[\operatorname{lnL}]{$^{2}$} & $0,014^{* *}$ & 0,012 & $0,055^{* *}$ \\
\hline & $(2,42)$ & $(2,00)$ & $(2,35)$ \\
\hline \multirow[t]{2}{*}{$\operatorname{lnL} \ln K$} & $0,043^{* * *}$ & $0,043^{* * *}$ & 0,018 \\
\hline & $(9,73)$ & $(8,83)$ & $(0,85)$ \\
\hline \multirow[t]{2}{*}{$\ln L^{*} \ln M$} & $-0,174^{* * *}$ & $-0,172^{* * *}$ & $-0,083^{* * *}$ \\
\hline & $(-39,88)$ & $(37,12)$ & $(-3,93)$ \\
\hline \multirow[t]{2}{*}{$\ln L^{*} \ln E$} & $0,067^{* * *}$ & $0,068^{* * *}$ & $-0,005$ \\
\hline & $(13,93)$ & $(13,10)$ & $(-0,21)$ \\
\hline \multirow[t]{2}{*}[\operatorname{ln}K]{$^{2}$} & $-0,003^{* *}$ & $-0,002^{*}$ & $0,013^{* *}$ \\
\hline & $(-2,38)$ & $(1,81)$ & $(2,41)$ \\
\hline \multirow[t]{2}{*}{$\ln K^{*} \ln M$} & $-0,071^{* * *}$ & $-0,074^{* * *}$ & $-0,081^{* * *}$ \\
\hline & $(-28,17)$ & $(-27,50)$ & $(-7,33)$ \\
\hline \multirow[t]{2}{*}{$\ln K^{*} \ln E$} & $0,057^{* * *}$ & $0,055^{* * *}$ & $0,035^{* * *}$ \\
\hline & $(22,86)$ & $(19,93)$ & $(2,51)$ \\
\hline \multirow[t]{2}{*}[\operatorname{ln}M]{$^{2}$} & $0,164^{* * *}$ & $0,167^{* * *}$ & $0,116^{* * *}$ \\
\hline & $(98,82)$ & $(97,94)$ & $(16,19)$ \\
\hline \multirow[t]{2}{*}{$\ln M^{*} \ln E$} & $-0,143^{* * *}$ & $-0,141^{* * *}$ & $-0,142^{* * *}$ \\
\hline & $(51,52)$ & $(-49,49)$ & $(-10,15)$ \\
\hline \multirow[t]{2}{*}[\operatorname{ln}E]{$^{2}$} & $0,023^{* * *}$ & $0,021^{* * *}$ & $0,051^{* * *}$ \\
\hline & $(17,69)$ & $(14,00)$ & $(5,25)$ \\
\hline \multirow[t]{2}{*}{$\mathrm{T}$} & $0,006^{* * *}$ & $0,011^{* * *}$ & $-0,011$ \\
\hline & $(3,79)$ & $(6,20)$ & $(-0,94)$ \\
\hline $\ln L^{*} \mathrm{~T}$ & $-0,001$ & $-0,000$ & $-0,002$ \\
\hline & $(0,54)$ & $(-0,78)$ & $(-0,49)$ \\
\hline $\ln K^{*} \mathrm{~T}$ & $-0,000$ & $-0,001$ & $0,009^{* * *}$ \\
\hline & $(-0,26)$ & $(-1,11)$ & $(4,31)$ \\
\hline $\ln M^{*} \mathrm{~T}$ & $0,001^{*}$ & $0,001^{* * *}$ & $-0,006^{* * *}$ \\
\hline & $(1,83)$ & $(2,95)$ & $(2,68)$ \\
\hline $\ln E^{*} \mathrm{~T}$ & $-0,004$ & $-0,001$ & 0,001 \\
\hline & $(-1,05)$ & $(-1,77)$ & $(0,26)$ \\
\hline $\mathrm{T}^{2}$ & $-0,001^{* * *}$ & $-0,001^{* * *}$ & $-0,000$ \\
\hline & $(-5,81)$ & $(-7,59)$ & $(0,76)$ \\
\hline Fungsi Inefisiensi & & & \\
\hline Konstanta & $0,078^{* * *}$ & $0,053^{* * *}$ & $0,222 * * *$ \\
\hline & $(21,59)$ & $(23,54)$ & $(13,93)$ \\
\hline PMA & $-0,008^{* * *}$ & $x^{2}$ & - \\
\hline & $(-6,56)$ & - & \\
\hline Spillover & $-0,126^{* * *}$ & $-0,150^{* * *}$ & $-0,261^{* * *}$ \\
\hline & $(-88,00)$ & $(-6,56)$ & $(-14,59)$ \\
\hline Age & $0,002^{* * *}$ & $0,00003^{* * *}$ & 0,00002 \\
\hline & $(3,30)$ & $(2,10)$ & $(0,07)$ \\
\hline Crisis & $0,015^{* * *}$ & $0,007^{* * *}$ & 0,004 \\
\hline & $(6,91)$ & $(10,31)$ & $(0,28)$ \\
\hline ioma-squared $\left(\sigma_{c}^{2}\right)$ & $0,033^{* * *}$ & $0,031^{* * *}$ & $0,047^{* * *}$ \\
\hline Igmid-squared $\left(O_{S}\right)$ & $(195,31)$ & $(142,70)$ & $(37,90)$ \\
\hline $\operatorname{Gamma}(\gamma)$ & $0,005^{* * *}$ & $0,137^{* * *}$ & $0,009^{* * *}$ \\
\hline & $(20,78)$ & $(18,23)$ & $(5,60)$ \\
\hline No. of Establishments & 3,318 & - & - \\
\hline No. of Observations & 43,134 & 40,042 & 3,092 \\
\hline
\end{tabular}

Catatan: ${ }^{* *}$ berarti signifikan pada derajat $\alpha=1 \%,{ }^{* *}$ berarti signifikan pada derajat $a=5 \%$, * berarti signifikan pada derajat $a=10 \%$. Sumber: Perhitungan penulis dari persamaan (13) dan persamaan (14). 
Masih pada hasil estimasi untuk data keseluruhan (kolom 2 Tabel 3), hasil estimasi untuk fungsi inefficiency menunjukkan bahwa perusahaan asing memiliki tingkat efisiensi yang lebih tinggi daripada perusahaan lokal pada periode waktu pengamatan. Hal ini ditunjukkan dari nilai negatif variabel PMA. ${ }^{1}$ Untuk variabel Spillover, nilai koefisien negatif dan signifikan menunjukan adanya efek rembesan yang positif dari keberadaan PMA terhadap efisiensi perusahaan di Indonesia. Nilai positif dan signifikan koefisien untuk variabel Age menunjukan bahwa bertambahnya usia perusahaan menyebabkan peningkatan inefficiency. Dengan kata lain, semakin tua perusahaan, semakin kurang efisien. Nilai positif koefisien Crisis menunjukan bahwa selama periode krisis ekonomi, inefficiency perusahaan di Indonesia meningkat.

Hasil yang menarik terlihat ketika perusahaan yang diobservasi dikelompokan menjadi perusahaan lokal dan perusahaan asing. Untuk perusahaan lokal (Kolom Ketiga Tabel 3), koefisien variabel Spillover bernilai negatif dan signifikan secara statistik, mengindikasikan bahwa terdapat efek rembesan positif dari PMA terhadap efisiensi perusahaan lokal. Sementara untuk perusahaan asing (Kolom Keempat Tabel 3), koefisien variabel Spillover juga positif dan signifikan, yang memberikan indikasi bahwa terdapat efek rembesan positif dari PMA terhadap efisiensi perusahaan asing yang telah ada dalam pasar. Perbedaan menarik terlihat dari besarnya koefisien. Terlihat bahwa koefisien Spillovers untuk perusahaan lokal lebih kecil daripada untuk perusahaan asing. Hal ini menunjukkan bahwa efek rembesan PMA lebih kecil pada perusahaan lokal daripada pada perusahaan asing lainnya. Temuan ini dapat dijelaskan melalui argumen teoritis yang dikemukakan oleh Lapan dan Badran (1973) bahwa teknologi gap dapat berpengaruh pada kemampuan perusahaan untuk mengimitasi dan mengadopsi teknologi baru dari keberadaan perusahaan asing baru dalam pasar. Temuan

Nilai negatif variabel PMA terhadap inefficiency memiliki arti bahwa perusahaan asing memiliki tingkat inefficiency yang lebih kecil daripada perusahaan lokal. Dengan kata lain, perusahaan asing memiliki efisiensi yang lebih tinggi daripada perusahaan lokal. ini merupakan salah satu kontribusi penting dari tulisan ini.

Dari hasil estimasi frontier produksi stokastik pada Tabel 3, dapat dihitung elastisitas output dari masing-masing input dan return to scale produksi setiap tahun pengamatan. Elastisitas output ini berguna untuk mengetahui implikasi ekonomi langsung dari input terhadap output. Hasil estimasi pada Tabel 3 merupakan hasil estimasi translog, yang tidak memperlihatkan implikasi total dari masing-masing input, dikarenakan adanya variabel interaksi antarinput dan variabel interaksi antar input dan waktu. Sehingga, diperlukan adanya perhitungan elastisitas output untuk melihat dampak total masing-masing input terhadap output di setiap tahun observasi. Tabel 4 memperlihatkan elastisitas output untuk masing-masing input dan return to scale (RTS).

Terlihat dari Tabel 4 bahwa elastisitas output terhadap tenaga kerja adalah sebesar ratarata 21 persen sepanjang tahun pengamatan. Modal memberikan sumbangan yang kecil terhadap pertumbuhan output. Sementara, bahan baku merupakan input yang memberikan kontribusi terbesar pada output. Hal ini dapat dimengerti karena sebagian besar perusahaan manufaktur Indonesia masih berorientasi pada kuantitas bahan baku yang dipergunakan. Modal masih menjadi faktor yang langka, sehingga kontribusinya masih relatif kecil terhadap output. Energi juga memberikan kontribusi yang tidak besar kepada output. Dengan demikian dapat disimpulkan bahwa pertumbuhan output di industri manufaktur Indonesia selama periode 1988-2000 sebagian besar dikontribusikan dari bahan baku. Peningkatan jumlah bahan baku masih merupakan faktor terpenting dalam pertumbuhan output. Pentingnya kontribusi bahan baku terhadap output semakin tinggi pada periode setelah krisis (1997-2000), yang terlihat dari meningkatkan nilai rata-rata elastisitas output dari bahan baku.

Nilai rata-rata return to scale (RTS) industri manufaktur Indonesia selama periode pengamatan adalah sebesar 1,06. Hal ini mengindikasikan bahwa terjadi tingkat kembalian yang meningkat (increasing return to scale) dari skala produksi. Peningkatan input secara bersama 
Tabel 4. Elastisitas Output dari Masing-masing Input dan Return to Scale (RTS) untuk Industri Manufaktur Indonesia

\begin{tabular}{|c|c|c|c|c|c|}
\hline Tahun & Tenaga Kerja & Modal & Bahan Baku & Energi & RTS \\
\hline 1988 & 0,22 & 0,09 & 0,62 & 0,10 & 1,03 \\
\hline 1989 & 0,22 & 0,09 & 0,63 & 0,09 & 1,03 \\
\hline 1990 & 0,21 & 0,08 & 0,66 & 0,08 & 1,03 \\
\hline 1991 & 0,22 & 0,09 & 0,63 & 0,09 & 1,03 \\
\hline 1992 & 0,20 & 0,08 & 0,67 & 0,08 & 1,03 \\
\hline 1993 & 0,21 & 0,09 & 0,66 & 0,08 & 1,04 \\
\hline 1994 & 0,21 & 0,09 & 0,67 & 0,07 & 1,05 \\
\hline 1995 & 0,20 & 0,09 & 0,69 & 0,07 & 1,06 \\
\hline 1996 & 0,20 & 0,09 & 0,72 & 0,06 & 1,07 \\
\hline 1997 & 0,20 & 0,09 & 0,73 & 0,06 & 1,08 \\
\hline 1998 & 0,21 & 0,10 & 0,73 & 0,06 & 1,10 \\
\hline 1999 & 0,21 & 0,10 & 0,76 & 0,06 & 1,12 \\
\hline 2000 & 0,20 & 0,09 & 0,80 & 0,05 & 1,14 \\
\hline 1998-1992 & 0,22 & 0,09 & 0,64 & 0,09 & 1,03 \\
\hline 1993-1996 & 0,21 & 0,09 & 0,68 & 0,07 & 1,05 \\
\hline $1997-2000$ & 0,21 & 0,09 & 0,75 & 0,06 & 1,11 \\
\hline $1988-2000$ & 0,21 & 0,09 & 0,69 & 0,07 & 1,06 \\
\hline
\end{tabular}

Sumber: Perhitungan penulis dari hasil estimasi frontier produksi stokastik untuk semua perusahaan pada Tabel 3 kolom kedua.

sebanyak satu kali, akan meningkatkan jumlah output lebih dari satu kali. Dengan demikian dapat diindikasikan bahwa industri manufaktur Indonesia secara rata-rata melakukan produksi dengan tingkat kembalian yang meningkat.

\section{Hasil Dekomposisi Pertumbuhan Total Factor Productivity}

Dari hasil estimasi pada Tabel 3, dapat dihitung dekomposisi pertumbuhan TFP dengan menggunakan persamaan (15), (16), dan (17). Nilai rata-rata tahunan pertumbuhan TFP, peningkatan efisiensi teknis (TEC), kemajuan teknologi (TC), dan peningkatan skala efisiensi (SE) diperlihatkan pada Tabel 5. Untuk data semua perusahaan, hasil estimasi memperlihatkan bahwa pertumbuhan rata-rata TFP industri manufaktur Indonesia sebesar 3,51 persen selama periode pengamatan. Pertumbuhan tertinggi terjadi pada periode liberalisasi perdagangan (1988-1992), dengan pertumbuhan rata-rata TFP sebesar 5,51 persen. Pertumbuhan tinggi juga terjadi pada tahun 1993 sampai 1996, yang mencapai rata-rata 5,02 persen. Hal yang menarik ditemukan pada periode krisis ekonomi (19972000), ketika rata-rata pertumbuhan TFP nega- tif. Indikasi dari temuan ini adalah krisis ekonomi yang melanda Indonesia pada 1997 memberikan dampak negatif yang besar terhadap pertumbuhan TFP.

Hal menarik selanjutnya yang ditemukan adalah pertumbuhan TFP industri manufaktur Indonesia digerakan oleh kemajuan teknologi (TC). Kontribusi kemajuan teknologi mencapai rata-rata 4,26 persen selama periode pengamatan. Kontribusi skala efisiensi (SEC) positif, meskipun tidak terlalu besar. Kontribusi efisiensi teknis (TEC) secara rata-rata negatif selama periode pengamatan. Kontribusi efisiensi teknis ini umumnya negatif pada periode krisis ekonomi, yang mengindikasikan bahwa krisis menurunkan efisiensi teknis perusahaan melalui keahlian manajemen yang menurun.

Hasil temuan semakin menarik ketika data observasi dibagi menjadi dua bagian, yaitu kelompok perusahaan asing dan kelompok perusahaan lokal. Selama periode pengamatan, terlihat bahwa pertumbuhan TFP perusahaan asing lebih tinggi daripada pertumbuhan TFP perusahaan lokal, masing-masing sebesar 4,62 persen dan 3,43 persen. Temuan ini dapat diartikan bahwa perusahaan asing memiliki pertumbuhan produktivitas yang lebih besar daripada perusahaan lokal. 


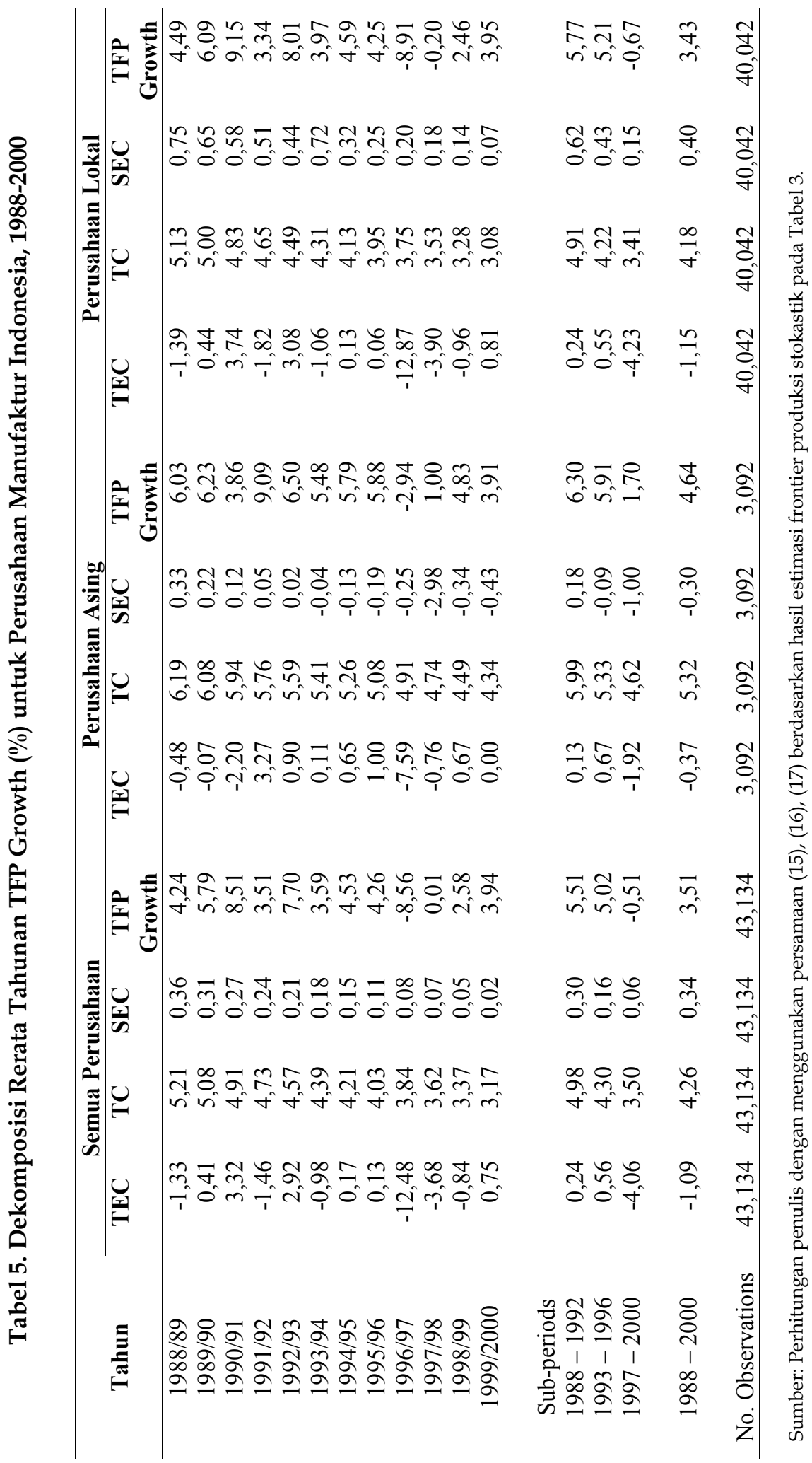


Ketika dianalisis lebih detail ke komponenkomponen produktivitas, terlihat bahwa kemajuan teknologi (TC) merupakan mesin penggerak pertumbuhan produktivitas di kedua kelompok perusahaan tersebut.

Pertumbuhan efisiensi skala (SEC) negatif untuk perusahaan asing tetapi positif untuk perusahaan lokal, mengindikasikan bahwa efisiensi skala perusahaan lokal suatu saat akan mencapai tingkat efisiensi yang sama dengan efisiensi perusahaan asing. Di sisi lain, pertumbuhan efisiensi teknis di kedua kelompok perusahaan secara rata-rata bernilai negatif selama periode pengamatan, meskipun nilai negatif lebih besar untuk kelompok perusahaan lokal dibandingkan kelompok perusahaan asing. Indikasi dari temuan ini adalah efisiensi teknis perusahaan lokal menurun lebih cepat daripada efisiensi teknis perusahaan asing. Sehingga, kemungkinan perusahaan lokal untuk melampaui perusahaan asing dalam hal efisiensi teknis, sangatlah kecil kemungkinannya.

Temuan menarik lainnya dari perbandingan hasil kedua kelompok perusahaan adalah percepatan kemajuan teknologi semakin menurun, terlihat dari menurunnya nilai TC selama tahun pengamatan. Pada 1988/1989, nilai TC perusahaan asing sebesar 6,19 persen dan nilai TC untuk perusahaan lokal sebesar 5,13 persen. Nilai ini menjadi sebesar 4,34 persen dan 3,08 persen untuk masing-masing kelompok perusahaan pada 1999/2000. Penurunan dalam percepatan kemajuan teknologi ini yang kemudian berimplikasi pada penurunan pertumbuhan TFP, dari 6,03 persen untuk perusahaan asing dan 4,49 persen untuk perusahaan lokal di tahun 1988/1989, menjadi hanya 3,91 persen dan 3,43 persen di tahun 1999/2000. Secara implisit dapat disimpulkan bahwa apabila penurunan kemajuan teknologi (TC) ini tidak diimbangi dengan percepatan peningkatan efisiensi teknis dan percepatan peningkatan efisiensi skala, maka pertumbuhan TFP growth akan terus menurun.

Perbandingan antara kedua kelompok perusahaan perlu dilakukan secara hati-hati. Nilai rata-rata pertumbuhan TFP dan komponennya, dihitung dengan jumlah observasi yang sangat berbeda. Pada kelompok perusahaan asing, jumlah observasi hanya mencakup 3.092 observasi. Sementara, kelompok perusahaan lokal sebanyak 40.042 observasi. Namun demikian, hasil estimasi dari kedua kelompok perusahaan ini dapat dijadikan dasar argumen karena telah mencakup sebagian besar perusahaan manufaktur di Indonesia.

\section{SIMPULAN}

Tulisan ini telah mengkaji dampak rembesan (spillovers) dari PMA terhadap produktivitas perusahaan lokal dan produktivitas perusahaan asing. Dari analisis frontier produksi stokastik, ditemukan bahwa perusahaan asing memiliki efisiensi dan produktivitas yang lebih tinggi daripada perusahaan asing. PMA memberikan efek rembesan positif terhadap perusahaan lokal berupa peningkatan efisiensi dan produktivitas. Kontribusi faktor input terbesar terhadap output berasal dari bahan baku, sedangkan modal dan energi memberikan kontribusi yang relatif kecil. Dari dekomposisi pertumbuhan produktivitas ditemukan bahwa pertumbuhan TFP positif sepanjang periode pengamatan, tetapi tingkat pertumbuhannya menurun, terutama saat krisis ekonomi 1997. Kemajuan teknologi merupakan kontributor utama pertumbuhan TFP, sementara peningkatan efisiensi teknis berkontribusi negatif. Sementara, peningkatan efisiensi skala memberikan kontribusi kecil, tetapi positif.

Ketika perusahaan yang diobservasi dikelompokan menjadi perusahaan asing dan perusahaan lokal, ditemukan juga bahwa kemajuan teknologi merupakan komponen utama yang berkontribusi pada pertumbuhan TFP. Perbedaan antarkedua kelompok perusahaan terjadi pada peningkatan skala efisiensi, yang bernilai negatif untuk perusahaan lokal tetapi bernilai positif untuk perusahaan asing, mengindikasikan bahwa efisiensi skala perusahaan lokal sangat tidak mungkin memcapai tingkat efisiensi skala yang sama dengan perusahaan asing. Dari efisiensi teknis, ditemukan bahwa terjadi penurunan pertumbuhan bagi perusahaan lokal maupun perusahaan asing. Hanya saja, penurunan pertumbuhan lebih besar pada perusahaan lokal dibandingkan pada perusa- 
haan asing.

Rekomendasi yang bisa diberikan berdasarkan hasil temuan pada penelitian ini adalah: Pertama, perusahaan-perusahaan di industri manufaktur perlu berhati-hati dengan penurunan percepatan kemajuan teknologi. Perusahaan dapat mencari solusi berupa penemuan teknologi baru yang akan meningkatkan kemajuan teknologi atau mencari cara untuk meningkatkan efisiensi teknis, sehingga efek rembesan dari PMA berupa peningkatan produktivitas dapat dirasakan oleh perusahaan lokal; Kedua, perusahaan lokal perlu mewaspadai penurunan percepatan efisiensi teknis dan efisiensi skala. Semakin menurunnya percepatan efisiensi teknis dapat mengindikasikan bahwa manajemen produksi yang dijalankan semakin tidak efisien. Sedangkan, semakin menurunnya percepatan efisiensi skala mengindikasikan bahwa skala produksi semakin tidak ekonomis. Hal ini dapat menyebabkan ketidakmampuan perusahaan lokal untuk mendapatkan efek rembesan dari PMA dalam bentuk efisiensi teknis dan efisiensi skala.

\section{DAFTAR PUSTAKA}

Adiningsih, S., M. Lestari, A. I. Rahutami, and A. S. Wijaya. 2009. Sustainable Development Impacts of Investment Incentives: A Case Study of the Chemical Industry in Indonesia. Manitoba, Canada: International Institute for Sustainable Development. http:// www.tradeknowledgenetwork.net/pdf/s d_investment_impacts_indonesia.pdf. Diakses tanggal 14 April 2009.

Barry, F., H. Gorg, dan E. Strobl (2005), Foreign Direct Investment and Wages in Domestic Firms in Ireland: Productivity Spillovers versus Labour-Market Crowding Out. International Journal of Business and Economics 12(1): $67-84$.

BPS. 1988-2001. Statistik Industri. Jakarta: Badan Pusat Statistik.

BPS. 1970-2009. Survei Industri Besar dan Menengah. Jakarta: Badan Pusat Statistik.
BI. 2000. Statistik Ekonomi dan Keuangan Indonesia. Jakarta: Bank Indonesia.

Blalock, G., and P. J. Gertler. 2005. How Firm Capacities Affect Who Benefits from Foreign Technology. Cornell University Working Paper.http://aem.cornell.edu/faculty_sites /gb78/wp/firmcap_022305.pdf. Diakses tanggal 1 April 2011.

Blalock, G., dan P. J. Gertler. 2008. Welfare Gain from Foreign Direct Investment through Technology Transfer to Local Suppliers. Journal of international Economics 74 (2): 402-421.

Chakraborty, C., and P. Nunnenkamp. 2008. Economic Reforms, FDI, and Economic Growth in India: A Sector Level Analysis. World Development 36 (7): 1192-1212.

Coelli, T. J. 1995. Estimators and Hypothesis Tests for A Stochastic: A Monte Carlo Analysis. Journal of Productivity Analysis 6(3): 247-268.

Coelli, T. J., D. S. P. Rao, C. J. O'Donnell, dan G. E. Battese. 2005. An Introduction to Efficiency and Productivity Analysis. 2nd ed. New York: Springer.

Fosfuri, A., M. Motta, dan T. Ronde. 2001. Foreign Direct Investment and Spillovers through Workers' Mobility. Journal of International Economics 53 (1): 205-222.

Girma, S., dan H. Gorg. 2007. Multinational's Productivity Advantage: Scale or Technology. Economic Inquiry 42 (2): 350-362.

Gorg, H., dan D. Greenaway. 2004. Much Ado about Nothing? Do Domestic Firms Really Benefit from Foreign Direct Investment? The World Bank Research Observer 19 (2): 171-197.

Gorg, H., dan E. Strobl. 2004. Foreign Direct Investment and Local Economic Development: Beyond Productivity Spillovers. Research Paper Series, University of Nottingham No. 2004/11.

Gorg, H., dan E. Strobl. 2005. Spillovers from Foreign Firms through Worker Mobility: 
An Empirical Investigation. Scandinavian Journal of Economics 107 (4): 693-739.

Haskel, J. E., S. C. Pereira, and M. J. Slaughter. 2007. Does Inward Foreign Direct Investment Boost the Productivity of Domestic Firms? The Review of Economics and Statistics 89 (3): 483-496.

Havranek, T. dan Z. Irsova. 2011. Estimating Vertical Spillovers from FDI: Why Results Vary and What the True Effect is? Journal of International Economics 85(2): 234-244.

Ikhsan, M. 2007. Total Factor Productivity Growth in Indonesian Manufacturing: A Stochastic Frontier Approach. Global Economic Review 36 (4): 321-342.

Javorcik, B. S. 2004. Does Foreign Direct Investment Increase the Productivity of Domestic Firms? In Search of Spillovers through Backward Linkages. American Economic Review 94 (3): 605-627.

Javorcik, B. S. 2008. Can Survey Evidence Shed Light on Spillovers from Foreign Direct Investment? The World Bank Research Observer 23 (2): 140-159.

Kokko, A., dan V. Kravtsova. 2008. Innovative Capability in MNC Subsidiaries: Evidence from Four European Transition Economies. Post-Communist Economies 20 (1): 5775.

Kravtsova, V., dan V. Zelenyuk. 2007. Foreign Knowledge, What does It Bring to Domestic Firms? Malmquist Productivity Index in Test for FDI Spillovers. Working Paper of UNU-MERIT.

Kugler, M. 2006. Spillovers from Foreign Direct Investment: Within or between industries? Journal of Development Economics 80 (2): 444-477.

Lapan, H., dan P. Bardhan. 1973. Localized Technical Progress and Transfer of Technology and Economic Development. Journal of Economic Theory 6 (6): 585-595.

Lee, Y. H. 2006. A Stochastic Production Frontier Model with Group-specific Tem- poral Variation in Technical Efficiency. European Journal of Operational Research 174 (3): 1616-1630.

Liu, Z. 2008. Foreign Direct Investment and Technology Spillovers: Theory and Evidence. Journal of Development Economics 85 (1-2): 176-193.

Mahadevan, R. 2003. To Measure or Not to Measure Total Factor Productivity Growth? Oxford Development Studies 31: 365-378.

Markusen, J. R., dan N. Trofimenko. 2007. Teaching Locals New Tricks: Foreign Experts as a Channel of Knowledge Transfer. NBER Working Paper No. 12872.

Orea, L. 2002. Parametric Decomposition of a Generalized Malmquist Productivity Index. Journal of Productivity Analysis 18 (1): 5-22.

Smeets, R. A. 2008. Collecting the Pieces of the FDI Knowledge Spillovers Puzzle. The World Bank Research Observer 23 (2): 107138.

Suyanto, R. A. Salim, dan H. Bloch. 2009. Does Foreign Direct Investment Lead to Productivity Spillovers? Firm Level Evidence from Indonesia. World Development 37(12): 1861-1871.

Suyanto dan R.A. Salim. 2010. Sources of Productivity Gains from FDI in Indonesia: Is It Efficiency Improvement or Technological Progress? The Developing Economies 48(4): 450-472.

Suyanto, H. Bloch, dan R.A. Salim. 2012. Foreign Direct Investment Spillovers and Productivity Growth in Indonesian Garment and Electronics Manufacturing, Journal of Development Studies, DOI: 10.1080/00220388.2011.646992, available online on: http://dx.doi.org/10. 1080/ 00220388.2011.646992.

Syamsudin dan Anton A. Setyawan. 2008. Foreign Direct Investment (FDI), Kebijakan Industri, dan Masalah Pengangguran: 
Studi Empirik di Indonesia, Jurnal Ekonomi Pembangunan 9(1): 106-118.

Takii, S. 2005. Productivity Spillovers and Characteristics of Foreign Multinational Plants in Indonesian Manufacturing 1990-95. Journal of Development Economics 76 (2): 521-542.

Thee, K. W. 2006. Policies for Private Sector Development in Indonesia. $A D B$ Institute Discussion Paper No. 46.

Tomohara, A., dan K. Yokota. 2006. Does Foreign Direct Investment Benefit Domestic Companies via Increased Productivity: Horizontal, Backward, and Forward Lin- kages. ICSEAD Working Paper Series. http://www.icsead.or.jp/7publication/w orkingpp/wp2006/2006-07.pdf (accessed June 27, 2007).

Todo, Y., dan K. Miyamoto. 2006. Knowledge Spillovers from Foreign Direct Investment and the Role of R\&D Activities: Evidence from Indonesia. Economic Development and Cultural Change 55 (1): 173-200.

Vial, V. 2006. New Estimates of Total Factor Productivity Growth in Indonesian Manufacturing. Bulletin of Indonesian Economic Studies 42 (3): 357-369. 